\title{
Changes in subsidence and uplift and the nighttime land surface temperature anomaly related the distance to the earthquake epicenter and the faults using Sentinel and MODIS imageries
}

Reza Ghorbani Kalkhajeh

Islamic Azad University of Yazd

Ali Akbar Jamali ( $\nabla$ jamhek@yahoo.com )

Islamic Azad University Meybod Branch https://orcid.org/0000-0002-1537-2427

\section{Research Article}

Keywords: Anomaly, statistical analysis, sentinel, earthquake epicenter, faults

Posted Date: April 20th, 2021

DOl: https://doi.org/10.21203/rs.3.rs-261695/v1

License: (a) (1) This work is licensed under a Creative Commons Attribution 4.0 International License.

Read Full License 


\section{Abstract}

When an earthquake occurs, the faults of the region usually heat the rocks and soil of the region due to their movements. The purpose of this study was to analyze the uplift, subsidence, cloud cover and changes in nighttime land surface temperature (nLST) anomalies around faults and the earthquake epicenter in Kermanshah, Iran (date and time of earthquake 12 November, 2017 at 18:18 Coordinated Universal Time (UTC) and at 21:48 Iranian time(. Heat changes were investigated by considering the effect of other cooling factors such as vegetation (EVI), land altitude and soil moisture, rainfall and water areas. Using the MODIS sensor product, the amount of cloud cover and cooling factors were obtained. Using sentinel $1 \mathrm{~A}$ the amount of earth uplift and subsidence were calculated. The results showed that using statistical analysis, a significant difference was observed in the nighttime land surface temperature around the faults and around the uplift and subsidence on the night of the accident, before and after night of earthquake. However, there was no significant difference between nighttime temperature and changes in the rate of spatial variation of cooling factors. It was found that the earthquake caused an increase in temperature at the fault and earthquake epicenter location. It also causes changes in height such as uplift and subsidence. Cloud cover situation showed before the earthquake, the cloud density was high and after the earthquake, the cloud density decreased. Crises managers can consider these results for monitoring metropolices for more readiness before earthquake accordance.

\section{Introduction}

The current progress in remote sensing sciences reveals different processes related with earthquakes i.e. earth's deformation, surface temperature anomaly, atmospheric gases, aerosol exhalation, ionospheric total electron content and electromagnetic disturbances in the ionosphere (Eleftheriou et al., 2016; Asim et al., 2017a, 2017b; Jilani et al., 2017; Barkat et al., 2017; Awais et al., 2017). Barkat et al., (2018) they have used MODIS thermal imagery for precursory analysis of Kashmir (Oct 8, 2005; Mw 7.6; $26 \mathrm{~km}$ ), Ziarat (Oct 28, 2008; Mw 6.4; $13 \mathrm{~km}$ ) and Dalbandin (Jan 18, 2011; Mw 7.2; $69 \mathrm{~km}$ ) earthquakes. They have obtained to this result that there exists an evident correlation of Land Surface Temperature (LST) anomalies with seismic and earthquake activity. These processes carry precursory information related with seismic and earthquakes and can serve as potential indicators within the context of earthquake predicting. Most of the precursory signals contain significant data and information for earthquake forecasting along with their limitations, but the satellite thermal infra-red (TIR) signal has gained more attention and support from the scientific and expert community across the world (Saradjian and Akhoondzadeh, 2011; Akhoondzadeh et al., 2018). This can be attributed to its ability of providing valuable precursory information prior to near or distant earthquakes (Xie et al., 2013; Eleftheriou et al., 2016; Bhardwaj et al., 2017).

Researches that are pointed to as 'thermal anomalies' have been reported to precede earthquakes worldwide since the 1980s see, for example, (Tronin, et al. 2002; Tramutoli et al., 2015; Khalili et al. 2020). Several references describe sudden increases in brightness temperatures (BT) recorded by satellite sensors (Lisi et al., 2010; Ouzounov et al., 2006; Tramutoli et al., 2001); in land surface temperatures 
derived using either satellite observations (SREEJITH et al., 2016; Lisi et al., 2015; Akhoondzadeh, 2013) or numerical simulations (Alvan et al., 2014; Qin et al 2012); in air temperatures recorded with groundbased meteorological stations (Pulinets and Dunajecka, 2007; Panda et al., 2007); in satellite-based outgoing longwave radiation (OLR) (Lu et al., 2016; Ouzounov et al., 2007); in surface latent heat flux (SLHF) (Cervone et al., 2006; Dey and Singh., 2003); and in soil temperatures measured in the field on-site (Rezapour et al., 2010; Liu et al., 1999). The physical link between observed anomalies and earthquakes has not been established so far, however, and the main reason can be traced back to methodological shortcomings in existing literature and background (Jordan et al., 2011). Definitions of what is an earthquake related thermal anomaly vary among researchers and among different methodologies. Observed anomalies also seem to vary for the same earthquake: they may appear a few hours (Akhoondzadeh, 2013) to a few years (Yao and Qiang, 2010) prior to an earthquake, and they may reappear shortly after an earthquake (Tronin, 2000; Zhang et al. 2021). The spatial extent of reported anomalies is not clear, because the spatial resolution of the input data andimages can be as limited as point observations from a meteorological station (e.g., (Jie and Guangmeng, 2013)) or as coarse as gridcells of * (e.g., (Singh et al., 2010)). Study areas are often limited, in location and in time, around the earthquake (e.g., approximately one month and only in the pixel covering the earthquake epicenter in (Akhoondzadeh, 2013; Ouzounov and Freund, 2004)). Such settings do not allow for detailed examination of the spatiotemporal coincidence of earthquakes with distinguished anomalies and do not permit to detect false positives. Statistical evaluation of the results is often missing and relevant discussion can be found rarely (Eneva et al., 2008). In addition, anomalies are often found to relate to atmospheric influences and artefacts due to data processing (Blackett et al., 2011). Pavlidou et al., (2016) considered that an earthquake is large when it has magnitude larger than Mw 5.5 and that an earthquake is shallow when it has focal depth $<35 \mathrm{~km}$. They studied 20 earthquake cases in 10 study areas around the world, with different local environmental and climatic conditions. They applied a methodology which suppresses large-scale patterns in the satellite signal time series and isolates only spatially localized fluctuations (Pavlidou et al., 2016). This methodology allows to limit the spatial extent of detected anomalies and the time of their occurrence. Thermal anomalies might appear for a variety of reasons other than earthquakes, including spatiotemporal variations of surface spectral emissivity (Tramutoli et al., 2005; Khalili et al. 2020) and local atmospheric conditions, like atmospheric inversions (QU and SHAN, 2006). (Pavlidou et al. (2016) tested the hypothesis that more anomalies would be detected at closer distances to the earthquake, shortly prior or during the earthquake, and only in years with earthquake occurrence. This hypothesis is supported by some published research such as (Xiong and Shen, 2017), concluding that nature anomalies increase with increasing earthquake magnitude; nature anomalies are found predominantly near the epicenter, one day before and on the day of the earthquake; and anomalies are more easily seen during shallow earthquakes than the deep ones. They statistically evaluated their findings, taking into account the spatial and temporal occurrence of detected anomalies and earthquakes. Also, Thermal infrared (TIR) remote sensing has recently emerged as a promising technique for distinguishing seismic precursors. Anomalous TIR emissions have been detected by satellite sensors before the occurrence of major earthquakes (Piroddi et al., 2014; Wei et al. 2020). Meanwhile, (Bellaoui et al., 2017) studied the 21 May 2003 Boumerdes earthquake and detected a TIR 
anomaly that had persisted for 1 week during the prior month (Bellaoui et al., 2017). Furthermore to analyzing the TIR anomalies for a single earthquake, (Tramutoli et al., 2013; Zhang et al. 2021) studied the causes of TIR anomalies a test over an area affected by variable gas emissions - to showe the correlation between TIR anomalies and seismicity and found that general gas dispersion models and spatial features lend support to the hypothesis of a robust correlation between greenhouse gas emissions and TIR anomalies related to seismic activity (Tramutoli et al., 2013; Wei et al. 2020).

Gaps seen in the background include unrelated uplift or subsidence to earthquakes, or nighttime temperature from satellite imagery and its association with proximity to faults or epicenters. In this study, filling these gaps was considered. Regarding the uniqueness of this research, it can be mentioned that using RAdio Detection And Ranging (radar) data from Sentinel satellite as images with new technology, the places that were affected by the earthquake were raised or subsided. Then, using data related to night temperature, satellite images, cloud cover, vegetation cover, humidity and water areas and other influencing factors, their impact around faults as well as areas with subsidence and uplift were investigated. The hypotheses were that there was a relationship between a significant increases in temperature in the days before, after and the day of the earthquake near the faults and the epicenter of the earthquake. There have also been landslides and subsidence near the epicenter. Another assumption is the presence of dense clouds in the days before the earthquake and their disappearance after the earthquake. The aim was to study the trend of changes in night temperature, uplift and subsidence of the areas around the fault and the epicenter of the earthquake in the occurrence of the earthquake by eliminating the factors that have a disturbing effect on temperature.

\section{Method}

\section{Study area}

The epicenter of the earthquake was Sarpol-e-Zahab city, which is adjacent to Thalas Baba Jani city from the north to Qasr Shirin city from the west, to Gilangharb from the south, and from Iraq and Qasr Shirin city from the west. The date and time of the earthquake, November 12, 2017, at 9:18 pm local time, was 7.3 magnitude in Kermanshah province, the border between Iran and Iraq. The average altitude of the city is 550 meters above sea level in a sudden change in altitude compared to the east of the city in a distance of less than $10 \mathrm{~km}$ to more than 1000 meters, which creates a very attractive and pleasant nature with the climate of the surrounding lands. In addition, this has created surface water currents and nourished the aquifers of the fertile plains of the city. Sar Pol-e Zahab city has a climate with mild winters and hot summers, with maximum rainfall in winter and a small amount of spring, and dry autumn and summer without rain. Based on the division has three different climates with mild winters and hot and long summers in the central part and cold winters and dull summers in the north and mild winters and hot summers in the northwest with an average rainfall of $500 \mathrm{~mm}$ per year and a temperature of $3.4{ }^{\circ} \mathrm{C}$ is the coldest month and $44.8^{\circ} \mathrm{C}$ is the hottest month of the year. In Figures 1, 2 and 3, you can see the anamolic diagrams of temperature, temperature and precipitation, and the diagram of temperature and precipitation distribution for Sarpol-e-Zahab region. 
(https://weatherspark.com/y/104353/Average-Weather-in-Kermanshah-Iran-Year-Round)

The $\mathrm{nLST}$ of case study (with minimum $-1.81^{\circ} \mathrm{C}$, maximum $17.75^{\circ} \mathrm{C}$ and mean $10.36^{\circ} \mathrm{C}$ with standard deviation $2.93^{\circ} \mathrm{C}$ ) were extracted for all of study points (number of points 5014).

The examiner of hypothesis was that in each buffer of surrounding surface earthquake epicenter, faults, subsidence area and uplift area, the range nLST was not the same. This hypothesis has been done with non-parametric statistical test of Kruskal-Wallis.

In addition the range of subsidence and uplift was calculated and was processed with RADAR images from sentinel-1A in C-band that has caught in 2017 November $7^{\text {th }}$ and $19^{\text {th }}$. (Table 1).

Table 1. Satellite images and their properties

\begin{tabular}{|c|c|c|c|c|c|c|}
\hline $\begin{array}{l}\text { Satellite- } \\
\text { Site }\end{array}$ & Sensor & Product & Date & dimension & $\begin{array}{l}\text { Spatial } \\
\text { resolution }\end{array}$ & bands \\
\hline MODIS & $\begin{array}{l}\text { MODIS- } \\
\text { Terra }\end{array}$ & MOD11A1 & $\begin{array}{l}\text { 2017.11.05- } \\
2017.11 .19\end{array}$ & $\begin{array}{l}1.0 \times 1.6 \times 1.0 \\
\mathrm{~m}\end{array}$ & $1 \mathrm{Km}$ & \\
\hline $\begin{array}{l}\text { Giovanni- } \\
\text { NASA }\end{array}$ & $\begin{array}{l}\text { MODIS- } \\
\text { Terra }\end{array}$ & Monthly & $\begin{array}{l}2017.11 .01- \\
2017.11 .30\end{array}$ & $\begin{array}{l}1.0 \times 1.6 \times 1.0 \\
\mathrm{~m}\end{array}$ & $0.05^{\circ}$ & \\
\hline sentinel & $\begin{array}{l}\text { sentinel- } \\
1 \mathrm{~A}\end{array}$ & $\longrightarrow$ & $\begin{array}{l}2017.11 .07- \\
2017.11 .19\end{array}$ & $\begin{array}{l}3.9 \mathrm{~m} \times 2.6 \mathrm{~m} \\
\times 2.5 \mathrm{~m}\end{array}$ & $5 m$ & $\begin{array}{l}\text { C- } \\
\text { band }\end{array}$ \\
\hline
\end{tabular}

The earthquake epicenter was specified and surrounding buffers was delineated in several circles to group area for nLST changing trend. The points with the equal distance (systematic) were made in buffers. Intersection of points with nLST was done in GIS environment for the area that earthquake took place. These points that were included data of temperature were intersected with different polygon buffers. Because of there were more two buffers (as groups) in each examination, the non-parametric statistical test of Kruskal-Wallis was chosen in analysis and process of hypothesizes. The relationship of night temperature and distance of surface earthquake epicenter and distance of faults were studied. The nLST map was included the two nights before and after of earthquake event. The distribution and scatter plot were examined and the gradient of the fit line in each process was compared. In control of that changing temperature in surrounding of earthquake epicenter or faults should be not originated by others criteria such as changing elevation, changing vegetation or water bodies (river, dam lakes...), those points was intersected with elevation, soil moisture and vegetation density maps. With zonal and intersect order in GIS, the mean and values of elevation, soil moisture and vegetation density in each buffer was identified. Then these changes were compared for statistical assessments. If the changes be same we subsequently can inference that earthquake could change nLST. If with far from earthquake epicenter the range of elevation, soil moisture and vegetation density change significantly, it expect that we face with the trend of changing temperature that can disarrange our hypothesis about changing temperature consequently changing $\mathrm{nLST}$ cannot be from the earthquake event. 


\section{Results And Discussion}

It was found that the difference in buffers is significant in terms of temperature. So, the temperature is higher near the earthquake epicenter or faults. The Kruskal-Wallis comparison results rejected the null hypothesis that the temperature was equal in buffers, and the difference in temperature was proved in buffers by rejecting null hypothesis. On the other hand, according to the obtained graphs, it turned out that the temperature $\left({ }^{\circ} \mathrm{C}\right)$ was higher in the buffers closer to the earthquake epicenter, faults, uplift $(\mathrm{cm})$, and subsidence $(\mathrm{cm})$ due to earthquake (Fig. 2). The scatter plots revealed that the distance to the earthquake epicenter and the land surface temperature of the night, showed the reverse relationship (slight negative line slope). Before and after the earthquake occurrence, the distribution of temperature and distance to the earthquake epicenter did not show a strong negative relationship, but just at the night of the earthquake occurrence, this relationship was shown to be strong negative. In the distance to the faults, the same results were shown.

Table 2. Hypothesis Test Summary, nLST difference across categories of earthquake epicenter Buffers. Asymptotic significances are displayed. The significance level is .05.

\begin{tabular}{|llll}
\hline Null Hypothesis & Test & Sig. & Decision \\
$\begin{array}{l}\text { The distribution of } \mathrm{nLST} \text { is the same across } \\
\text { categories of earthquake epicenter Buffers. }\end{array}$ & $\begin{array}{l}\text { Independent-Samples } \\
\text { Kruskal-Wallis Test }\end{array}$ & .000 & $\begin{array}{l}\text { Reject the } \\
\text { null } \\
\text { hypothesis. }\end{array}$ \\
\hline
\end{tabular}

Thermal anomalies and earthquake clouds have been considered by many earthquake researchers. Prior to the Bam earthquake, thermal anomalies by (Arun and Choudhury, 2004) used AVHRR satellite data in the 90 days before the earthquake. Shou (1999), using the theory of earthquake clouds and relying on satellite images, predicted the 2003 Bam earthquake struck the Kerman province of southeastern Iran at 01:56 Coordinated Universal Time (UTC) (5:26 AM Iran Standard Time) on December 26. Images related to the cloud were also taken twelve days before and one week after the earthquake (Fig. 3). These images show that before the earthquake, the cloud density in the region was high and after the earthquake, the cloud density decreased.

In this study, thermal anomaly images in five months before and three months after the earthquake were prepared using MODIS sensor products (Fig. 4).

\section{Statistical study of temperature changes around the epicenter}

The null hypothesis is that the temperatures are equal in all the buffers around the epicenter, the rejection of which means that the buffer temperatures were statistically different. This indicates clear and significant thermal changes around the surface epicenter of the earthquake. Graphs and data also show that the temperature near the epicenter was higher than around (Fig. 5). 
Then the average altitude buffers were obtained from the zonal function and the altitude changes were compared with the temperature changes in the region to control the ineffectiveness of altitude on the warmer epicenter. Colder areas farther from the epicenter were not due to higher altitudes. Also, features such as river or vegetation that form areas with lower temperatures were controlled in the same way and it was found that the low temperature was not due to the density of these natural features.

Statistical study of temperature changes with distance from faults, uplift and subsidenceStatistical comparisons around faults in strips at distances of 1000, 3000, and $5000 \mathrm{~m}$ showed a significant difference (Table 3). As it moved away from the fault line, the nighttime temperature in the bands decreased. Similarly, significant temperature differences were observed around the uplifted area caused by the earthquake. There was a decrease in temperature as we moved away from the bulge area as well as the subsidence area caused by the earthquake (Fig. 6).

Table 3. Hypothesis Test Summary, Asymptotic significances are displayed. The significance level is .05.

\begin{tabular}{|llcl|}
\hline Null Hypothesis & Test & Sig. & Decision \\
\hline $\begin{array}{l}\text { The distribution of nLST is the same across } \\
\text { categories of fault Buffer. }\end{array}$ & $\begin{array}{l}\text { Independent-Samples } \\
\text { Kruskal-Wallis Test }\end{array}$ & .000 & $\begin{array}{l}\text { Reject the } \\
\text { null } \\
\text { hypothesis. }\end{array}$ \\
\hline $\begin{array}{l}\text { The distribution of nLST is the same across } \\
\text { categories of uplift Buffer. }\end{array}$ & $\begin{array}{l}\text { Independent-Samples } \\
\text { Kruskal-Wallis Test }\end{array}$ & .041 & $\begin{array}{l}\text { Reject the } \\
\text { null } \\
\text { hypothesis. }\end{array}$ \\
\hline $\begin{array}{l}\text { The distribution of nLST is the same across } \\
\text { categories of subsidence Buffer. }\end{array}$ & $\begin{array}{l}\text { Independent-Samples } \\
\text { Kruskal-Wallis Test }\end{array}$ & .016 & $\begin{array}{l}\text { Reject the } \\
\text { null } \\
\text { hypothesis. }\end{array}$ \\
\hline
\end{tabular}

\section{Ordinary least squares (OLS)}

Ordinary least squares or OLS Regression In statistics, ordinary least squares (OLS) is a type of linear least squares method for estimating the unknown parameters in a linear regression model.

Calculations were also performed with unclassified or unbuffered data from the earthquake epicenter and night temperature. Kolmogorov-Smirnov test or K-S test, which is for normal data, which is not significant thus indicates the data is not normal. Therefore, non-parametric statistics were used. In these calculations, the number of data was 770 and the slope of the regression line was -0.27 , which indicates the negative relationship between these two factors. That is, the greater the distance from the epicenter of the earthquake, the lower the temperature. This confirms the research hypothesis (Table 4, Table 5, and Table 6).

Table 4 nLSTdata on the night of the earthquake in the epicenter zone 


\begin{tabular}{|ll|}
\hline Dependent Variable & nLST in earthquake epicenter zone \\
\hline $\mathrm{N}$ & 770 \\
\hline Multiple R & 0.269 \\
\hline Squared Multiple R & 0.072 \\
\hline Adjusted Squared Multiple R & 0.071 \\
\hline Standard Error of Estimate & 1.468 \\
\hline
\end{tabular}

Table 5 Parameters and regression coefficients of distance from the epicenter of the earthquake and night surface temperature

\begin{tabular}{|lllllll|}
\hline \multicolumn{2}{|l|}{ Regression Coefficients $\mathrm{B}=\left(\mathrm{X}^{\prime} \mathrm{X}\right)^{-1} \mathrm{X}^{\prime} Y$} & & & & & \\
Effect & Coefficient & $\begin{array}{l}\text { Standard } \\
\text { Error }\end{array}$ & $\begin{array}{l}\text { Std. } \\
\text { Coefficient }\end{array}$ & Tolerance & $\mathrm{t}$ & $\begin{array}{l}\text { p- } \\
\text { Value }\end{array}$ \\
CONSTANT & 8.661 & 0.159 & 0.000 & 0.01 & 54.623 & 0.000 \\
DIST_TO_EQ_CENTER & 0.000 & 0.000 & -0.269 & 1.000 & -7.740 & 0.000 \\
\hline
\end{tabular}

Table 6 Analysis of variance for distance from the epicenter of the earthquake and night surface temperature

\begin{tabular}{|c|c|c|c|c|c|}
\hline \multicolumn{6}{|c|}{ Analysis of Variance } \\
\hline Source & SS & df & Mean Squares & F-Ratio & $p$-Value \\
\hline Regression & 129.038 & 1 & 129.038 & 59.906 & 0.000 \\
\hline Residual & $1,654.259$ & 768 & 2.154 & & \\
\hline
\end{tabular}

With unclassified or unbuffered data, the distance from the fault and the night temperature were also evaluated for normality. The data were not normal and the number of data was 2138 and the slope of the regression line was -0.13 . The regression was significant at the 0.99 confidence level. This negative relationship also shows the inverse relationship between these two factors. That is, the greater the distance from the fault, the lower the temperature. This confirms the research hypothesis (Table 7, Table 8, and Table 9).

Table $7 \mathrm{nLSTdata}$ on the night of the earthquake in the fault zones 


\begin{tabular}{|ll|}
\hline Dependent Variable & nLST in earthquake fault zone \\
\hline N & 2,138 \\
\hline Multiple R & 0.131 \\
\hline Squared Multiple R & 0.017 \\
\hline Adjusted Squared Multiple R & 0.017 \\
\hline Standard Error of Estimate & 1.818 \\
\hline
\end{tabular}

Table 8 Parameters and regression coefficients of distance from the faults and night surface temperature

\begin{tabular}{|lllllll|}
\hline Regression Coefficients $B=\left(X^{\prime} X\right)^{-1} X^{\prime} Y$ & & & & \\
Effect & Coefficient & $\begin{array}{l}\text { Standard } \\
\text { Error }\end{array}$ & $\begin{array}{l}\text { Std. } \\
\text { Coefficient }\end{array}$ & Tolerance & $t$ & $\begin{array}{l}\text { p- } \\
\text { Value }\end{array}$ \\
\hline CONSTANT & 7.608 & 0.072 & 0.000 & 0.01 & 105.184 & 0.000 \\
\hline DIST_TO_FAULT & 0.000 & 0.000 & -0.131 & 1.000 & -6.094 & 0.000 \\
\hline
\end{tabular}

Table 9 Analysis of variance for distance from the faults and night surface temperature

\begin{tabular}{|c|c|c|c|c|c|}
\hline \multicolumn{6}{|c|}{ Analysis of Variance } \\
\hline Source & SS & $d f$ & Mean Squares & F-Ratio & p-Value \\
\hline Regression & 122.705 & 1 & 122.705 & 37.138 & 0.000 \\
\hline Residual & $7,057 \cdot 346$ & 2,136 & 3.304 & & \\
\hline
\end{tabular}

In assessment of height, vegetation, and water impacts on $\mathrm{nLST}$, it was found that changes in altitude in buffer were not significant due to distance from the earthquake epicenter and faults. Therefore, altitude changes did not effect on the nLST. Additionally, with the distance from the earthquake epicenter and faults, the amount of vegetation density did not significantly decrease or increase and this factor also did not effect on $\mathrm{nLST}$ changes. Furthermore, Lakes and rivers have the equal distribution around the earthquake epicenter. In addition, distribution of soil moisture in area was same in statistical assessment. Thus, the nLST changes did not due to water distributions or soil moisture differences. These are consistent with the researches (Piroddi et al., 2014; Wei et al. 2020).

Independent-Samples Kruskal-Wallis Test was done for cooler factors (Table 7, and Fig. 11). These are statistical analysis consistent with this research (Eneva et al., 2008) and advances mentioned in (Zhao et 
al. 2021). The result of this test showed no factors had significant change around the faults and the epicenter, thus changes of the nLST are proved can occur just from the earthquake.

Table 10. Uplift cooler factors test, Hypothesis Test Summary, Asymptotic significances are displayed. The significance level is .050 .

\begin{tabular}{|llcl|}
\hline Null Hypothesis & Test & Sig. & Decision \\
\hline $\begin{array}{l}\text { The distribution of precipitation }(\mathrm{mm} . \mathrm{hr}-1) \\
\text { same across categories of Distance }(\mathrm{m}) \text {. }\end{array}$ & $\begin{array}{l}\text { Independent-Samples } \\
\text { Kruskal-Wallis Test }\end{array}$ & .108 & $\begin{array}{l}\text { Retain the } \\
\text { null } \\
\text { hypothesis. }\end{array}$ \\
\hline $\begin{array}{l}\text { The distribution of EVI is the same across } \\
\text { categories of Distance }(\mathrm{m}) .\end{array}$ & $\begin{array}{l}\text { Independent-Samples } \\
\text { Kruskal-Wallis Test }\end{array}$ & .421 & $\begin{array}{l}\text { Retain the } \\
\text { null } \\
\text { hypothesis. }\end{array}$ \\
\hline $\begin{array}{l}\text { The distribution of Soil Moisture }(\mathrm{Kg} . \mathrm{m}-2) \text { is the } \\
\text { same across categories of Distance }(\mathrm{m}) .\end{array}$ & $\begin{array}{l}\text { Independent-Samples } \\
\text { Kruskal-Wallis Test }\end{array}$ & .677 & $\begin{array}{l}\text { Retain the } \\
\text { null } \\
\text { hypothesis. }\end{array}$ \\
\hline $\begin{array}{l}\text { The distribution of DEM }(\mathrm{m}) \text { is the same across } \\
\text { categories of Distance }(\mathrm{m}) .\end{array}$ & $\begin{array}{l}\text { Independent-Samples } \\
\text { Kruskal-Wallis Test }\end{array}$ & .085 & $\begin{array}{l}\text { Retain the } \\
\text { null } \\
\text { hypothesis. }\end{array}$ \\
\hline
\end{tabular}

In this study, the reverse relationship between nLST, distance from earthquake epicenter and the distance from the fault were proved. In many studies, the nLST was not used, which is the strength and unique aspect of our research (Tramutoli et al., 2005; Tramutoli et al., 2013; Wei et al. 2020; Khalili et al. 2020). The nLST makes it possible to check and assess the real effect of the heat generated from these sources while in the daytime LST the effect of the heat of the sun makes some errors.

\section{Conclusion}

In this research was studied and used a combination of RADAR remote sensing techniques, thermal remote sensing, GIS integration, and statistical analysis. These explorations, propose to use the night data in an online bed, to improve the alert of the earthquake events. These explorations could test the complex factors and behaviors and their relationships.

Limitations in this study are high uncertainty in the study of cloud status. There were few sources on this. During an earthquake, the interference of heat from different sources of heat or cold in some cases, low temperature changes is one of the limitations of this study. The use of points in spatial statistical analysis of earthquake-related factors was a strong point in this study. The advantages of this method are the use of a set of data, including subsidence and uplift using radar images, as well as the use of nLST anomaly using satellite thermal images, as well as considering the factors of changes in clouds position in earthquake. The implications and applications of this study are in identifying areas similar to the study area. This can prepare governments for retrofitting buildings. In some cases, by studying the 
temperature changes according to the position of the faults and in some cases according to the condition of the clouds to some extent to warn of earthquakes to be effective. It is also possible to perform the necessary crisis management operations by zoning cities and provinces, according to the factors of faults, heat, clouds, and land subsidence in high-risk areas. Crisis organizations can take further steps to reduce earthquake hazards via completing this research.

\section{Declarations}

Funding (Private funding by authors)

Conflicts of interest/Competing interests (None)

Availability of data and material (Data are available when requested)

Code availability (Giovanni NASA online app)

Authors' contributions (Author1: Conceptualization, Methodology, Investigation, Formal analysis, Resources, Data Curation, Software Author2: Conceptualization, Methodology, Investigation, Validation, Resources, Data Curation, Software, Writing-Review \& Editing, Supervision, and Project administration)

\section{References}

Akhoondzadeh, M. (2013). A comparison of classical and intelligent methods to detect potential thermal anomalies before the 11 August 2012 Varzeghan, Iran, earthquake ( $\mathrm{M} \mathrm{w}=6.4)$. Natural Hazards and Earth System Sciences, 13(4), 1077-1083. https://doi.org/10.5194/nhess-13-1077-2013

Akhoondzadeh, M. (2013). An Adaptive Network-based Fuzzy Inference System for the detection of thermal and TEC anomalies around the time of the Varzeghan, Iran, $(M w=6.4)$ earthquake of 11 August 2012. Advances in Space Research, 52(5), 837-852. https://doi.org/10.1016/j.asr.2013.05.024

Akhoondzadeh, M., De Santis, A., Marchetti, D., Piscini, A., \& Cianchini, G. (2018). Multi precursors analysis associated with the powerful Ecuador (MW=7.8) earthquake of 16 April 2016 using Swarm satellites data in conjunction with other multi-platform satellite and ground data. Advances in Space Research, 61(1), 248-263. https://doi.org/10.1016/j.asr.2017.07.014

Allen, R. G., Tasumi, M., Trezza, R., Waters, R., \& Bastiaanssen, W. (2002). SEBAL (surface energy balance algorithms for land). Advance Training and Users Manual-Idaho Implementation, version, 1, 97.

Alvan, H. V., Mansor, S., Omar, H., \& Azad, F. H. (2014). Precursory signals associated with the 2010 M8. 8 Bio-Bio earthquake (Chile) and the 2010 M7. 2 Baja California earthquake (Mexico). Arabian Journal of Geosciences, 7(11), 4889-4897. https://doi.org/10.1007/s12517-013-1117-9 
Asim, K. M., Awais, M., Martínez-Álvarez, F., \& Iqbal, T. (2017b). Seismic activity prediction using computational intelligence techniques in northern Pakistan. Acta Geophysica, 65(5), 919-930. https://doi.org/10.1007/s11600-017-0082-1

Asim, K. M., Martínez-Álvarez, F., Basit, A., \& Iqbal, T. (2017a). Earthquake magnitude prediction in Hindukush region using machine learning techniques. Natural Hazards, 85(1), 471-486.

https://doi.org/10.1007/s11069-016-2579-3

Awais, M., Barkat, A., Ali, A., Rehman, K., Zafar, W. A., \& Iqbal, T. (2017). Satellite thermal IR and atmospheric radon anomalies associated with the Haripur earthquake (Oct 2010; Mw 5.2), Pakistan. Advances in Space Research, 60(11), 2333-2344. https://doi.org/10.1016/j.asr.2017.08.034

Barkat, A., Ali, A., Rehman, K., Awais, M., Riaz, M. S., \& Iqbal, T. (2018). Thermal IR satellite data application for earthquake research in Pakistan. Journal of Geodynamics, 116, 13-22.

https://doi.org/10.1016/j.jog.2018.01.008

Barkat, A., Ali, A., Siddique, N., Alam, A., Wasim, M., \& lqbal, T. (2017). Radon as an earthquake precursor in and around northern Pakistan: A case study. Geochemical Journal, 51(4), 337-346. https://doi.org/10.2343/geochemj.2.0473

Bellaoui, M., Hassini, A., \& Bouchouicha, K. (2017). Pre-seismic anomalies in remotely sensed land surface temperature measurements: The case study of 2003 Boumerdes earthquake. Advances in Space Research, 59(10), 2645-2657. https://doi.org/10.1016/j.asr.2017.03.004

Bhardwaj, A., Singh, S., Sam, L., Joshi, P. K., Bhardwaj, A., Martín-Torres, F. J., \& Kumar, R. (2017). A review on remotely sensed land surface temperature anomaly as an earthquake precursor. International journal of applied earth observation and geoinformation, 63, 158-166. https://doi.org/10.1016/j.jag.2017.08.002

Blackett, M., Wooster, M. J., \& Malamud, B. D. (2011). Exploring land surface temperature earthquake precursors: A focus on the Gujarat (India) earthquake of 2001. Geophysical Research Letters, 38(15). https://doi.org/10.1029/2011GL048282

Cervone, G., Maekawa, S., Singh, R. P., Hayakawa, M., Kafatos, M., \& Shvets, A. (2006). Surface latent heat flux and nighttime LF anomalies prior to the $\mathrm{M} w=8.3$ Tokachi-Oki earthquake. Natural Hazards and Earth System Science, 6(1), 109-114. https://doi.org/10.5194/nhess-6-109-2006

Córdova, M., Carrillo-Rojas, G., Crespo, P., Wilcox, B., \& Célleri, R. (2015). Evaluation of the PenmanMonteith (FAO 56 PM) method for calculating reference evapotranspiration using limited data. Mountain Research and Development, 35(3), 230-239.

Dey, S., \& Singh, R. P. (2003). Surface latent heat flux as an earthquake precursor. Natural Hazards and Earth System Science, 3(6), 749-755. https://doi.org/10.5194/nhess-3-749-2003 
Duffie, J. A., \& Beckman, W. A. (2013). Solar engineering of thermal processes. John Wiley \& Sons. https://doi.org/10.1002/9781118671603

Eleftheriou, A., Filizzola, C., Genzano, N., Lacava, T., Lisi, M., Paciello, R., ... \& Tramutoli, V. (2016). Longterm RST analysis of anomalous TIR sequences in relation with earthquakes occurred in Greece in the period 2004-2013. Pure and Applied Geophysics, 173(1), 285-303. https://doi.org/10.1007/s00024-015$1116-8$

Eneva, M. A. R. I. A. N. A., Adams, D., Wechsler, N., Ben-Zion, Y., \& Dor, O. (2008). Thermal properties of faults in southern California from remote sensing data. San Diego, California, USA: Imagair Inc. contracted by NASA Goddard Space Flight Center, SAIC n. NNH05CC13C.

Jie, Y., \& Guangmeng, G. (2013). Preliminary analysis of thermal anomalies before the 2010 Baja California M7. 2 earthquake. Atmósfera, 26(4), 473-477. https://doi.org/10.1016/S0187-6236(13)71089-0

Jilani, Z., Mehmood, T., Alam, A., Awais, M., \& Iqbal, T. (2017). Monitoring and descriptive analysis of radon in relation to seismic activity of Northern Pakistan. Journal of environmental radioactivity, 172, 4351. https://doi.org/10.1016/j.jenvrad.2017.03.010

Jordan, T. H., Chen, Y. T., Gasparini, P., Madariaga, R., Main, I., Marzocchi, W., ... \& Zschau, J. (2011). Operational earthquake forecasting. State of knowledge and guidelines for utilization. Annals of Geophysics, 54(4).

Khalili, M., Eskandar, S. S. A., \& Panah, S. K. A. (2020). Thermal anomalies detection before Saravan earthquake (April 16th, 2013, M W= 7.8) using time series method, satellite, and meteorological data. Journal of Earth System Science, 129(1), 5.

Lisi, M., Filizzola, C., Genzano, N., Grimaldi, C. S. L., Lacava, T., Marchese, F., ... \& Tramutoli, V. (2010). A study on the Abruzzo 6 April 2009 earthquake by applying the RST approach to 15 years of AVHRR TIR observations. Natural Hazards and Earth System Sciences, 10(2), 395-406.

https://doi.org/10.5194/nhess-10-395-2010

Lisi, M., Filizzola, C., Genzano, N., Paciello, R., Pergola, N., \& Tramutoli, V. (2015). Reducing atmospheric noise in RST analysis of TIR satellite radiances for earthquakes prone areas satellite monitoring. Physics and Chemistry of the Earth, Parts A/B/C, 85, 87-97. https://doi.org/10.1016/j.pce.2015.07.013

Liu, D. F., Peng, K. Y., Liu, W. H., Li, L. Y., \& Hou, J. S. (1999). Thermal omens before earthquakes. ACTA seismologica sinica, 12(6), 710-715. https://doi.org/10.1007/s11589-999-0072-8

Lu, X., Meng, Q. Y., Gu, X. F., Zhang, X. D., Xie, T., \& Geng, F. (2016). Thermal infrared anomalies associated with multi-year earthquakes in the Tibet region based on China's FY-2E satellite data. Advances in Space Research, 58(6), 989-1001. https://doi.org/10.1016/j.asr.2016.05.038 
Ouzounov, D., \& Freund, F. (2004). Mid-infrared emission prior to strong earthquakes analyzed by remote sensing data. Advances in space research, 33(3), 268-273. https://doi.org/10.1016/S0273-

1177(03)00486-1

Ouzounov, D., Bryant, N., Logan, T., Pulinets, S., \& Taylor, P. (2006). Satellite thermal IR phenomena associated with some of the major earthquakes in 1999-2003. Physics and Chemistry of the Earth, Parts $A / B / C$, 31(4-9), 154-163. https://doi.org/10.1016/j.pce.2006.02.036

Ouzounov, D., Liu, D., Chunli, K., Cervone, G., Kafatos, M., \& Taylor, P. (2007). Outgoing long wave radiation variability from IR satellite data prior to major earthquakes. Tectonophysics, 431(1-4), 211-220. https://doi.org/10.1016/j.tecto.2006.05.042

Panda, S. K., Choudhury, S., Saraf, A. K., \& Das, J. D. (2007). MODIS land surface temperature data detects thermal anomaly preceding 8 October 2005 Kashmir earthquake. International Journal of Remote Sensing, 28(20), 4587-4596. https://doi.org/10.1080/01431160701244906

Parida, B. R., Collado, W. B., Borah, R., Hazarika, M. K., \& Samarakoon, L. (2008). Detecting drought-prone areas of rice agriculture using a MODIS-derived soil moisture index. GIScience \& Remote Sensing, 45(1), 109-129. https://doi.org/10.2747/1548-1603.45.1.109

Pavlidou, E., van der Meijde, M., van der Werff, H., \& Hecker, C. (2016). Finding a needle by removing the haystack: A spatio-temporal normalization method for geophysical data. Computers \& geosciences, 90, 78-86. https://doi.org/10.1016/j.cageo.2016.02.016

Piroddi, L., Ranieri, G., Freund, F., \& Trogu, A. (2014). Geology, tectonics and topography underlined by L'Aquila earthquake TIR precursors. Geophysical Journal International, 197(3), 1532-1536.

https://doi.org/10.1093/gji/ggu123

Potić, I., Bugarski, M., \& Matić-Varenica, J. (2017, March). Soil Moisture Determination using Remote Sensing data for the property protection and increase of agriculture production. In Worldbank conference on land and poverty", The World Bank, Washington DC.

Pulinets, S. A., \& Dunajecka, M. A. (2007). Specific variations of air temperature and relative humidity around the time of Michoacan earthquake M8. 1 Sept. 19, 1985 as a possible indicator of interaction between tectonic plates. Tectonophysics, 431(1-4), 221-230. https://doi.org/10.1016/j.tecto.2006.05.044

Qin, K., Wu, L. X., Santis, A. D., Meng, J., Ma, W. Y., \& Cianchini, G. (2012). Quasi-synchronous multiparameter anomalies associated with the 2010-2011 New Zealand earthquake sequence. Natural Hazards and Earth System Sciences, 12(4), 1059-1072. https://doi.org/10.5194/nhess-12-1059-2012

QU, C. Y., Ma, J., \& SHAN, X. J. (2006). Counterevidence for an earthquake precursor of satellite thermal infrared anomalies. Chinese Journal of Geophysics, 49(2), 426-431. https://doi.org/10.1002/cjg2.851 
Rezapour, N., Fattahi, M., \& Bidokhti, A. A. (2010). Possible soil thermal response to seismic activities in Alborz region (Iran). Natural Hazards and Earth System Sciences, 10(3). https://doi.org/10.5194/nhess$10-459-2010$

Rouse Jr, J., Haas, R. H., Schell, J. A., \& Deering, D. W. (1974). Monitoring vegetation systems in the Great Plains with ERTS.

Saradjian, M. R., \& Akhoondzadeh, M. (2011). Thermal anomalies detection before strong earthquakes $(M>6.0)$ using interquartile, wavelet and Kalman filter methods. Natural Hazards and Earth System Sciences, 11(4), 1099-1108. https://doi.org/10.5194/nhess-11-1099-2011

Saraf, A. K., \& Choudhury, S. (2004). Satellite detects pre-earthquake thermal anomalies associated with past major earthquakes. Proceedings of Map Asia, 40.

Shou, Z. (1999). Earthquake clouds and short term prediction. Published in Science and Utopya, 64, 5357.

Singh, R. P., Mehdi, W., Gautam, R., Senthil Kumar, J., Zlotnicki, J., \& Kafatos, M. (2010). Precursory signals using satellite and ground data associated with the Wenchuan Earthquake of 12 May 2008. International Journal of Remote Sensing, 31(13), 3341-3354. https://doi.org/10.1080/01431161.2010.487503

SREEJITH, K., SREEKUMAR, V., NIRMESH, T., \& SUGANTHASAKTHIVEL, R. (2016). Thermal anomaly from NOAA data for the Nepal earthquake. Current Science, 110(2), 150.

Tramutoli, V., Aliano, C., Corrado, R., Filizzola, C., Genzano, N., Lisi, M., ... \& Pergola, N. (2013). On the possible origin of thermal infrared radiation (TIR) anomalies in earthquake-prone areas observed using robust satellite techniques (RST). Chemical Geology, 339, 157-168.

https://doi.org/10.1016/j.chemgeo.2012.10.042

Tramutoli, V., Corrado, R., Filizzola, C., Genzano, N., Lisi, M., \& Pergola, N. (2015). From visual comparison to Robust Satellite Techniques: 30 years of thermal infrared satellite data analyses for the study of earthquake preparation phases. Bollettino di Geofisica Teorica ed Applicata, 56(2).

Tramutoli, V., Cuomo, V., Filizzola, C., Pergola, N., \& Pietrapertosa, C. (2005). Assessing the potential of thermal infrared satellite surveys for monitoring seismically active areas: The case of Kocaeli (Izmit) earthquake, August 17, 1999. Remote Sensing of Environment, 96(3-4), 409-426.

https://doi.org/10.1016/j.rse.2005.04.006

Tramutoli, V., Di Bello, G., Pergola, N., \& Piscitelli, S. (2001). Robust satellite techniques for remote sensing of seismically active areas.

Tronin, A. A. (2000). Thermal IR satellite sensor data application for earthquake research in China. International Journal of Remote Sensing, 21(16), 3169-3177.

https://doi.org/10.1080/01431160050145054

Page 15/24 
Tronin, A. A., Hayakawa, M., \& Molchanov, O. A. (2002). Thermal IR satellite data application for earthquake research in Japan and China. Journal of Geodynamics, 33(4-5), 519-534.

Wang, L., \& Qu, J. J. (2009). Satellite remote sensing applications for surface soil moisture monitoring: A review. Frontiers of Earth Science in China, 3(2), 237-247. https://doi.org/10.1007/s11707-009-0023-7

Wei, C., Lu, X., Zhang, Y., Guo, Y., \& Wang, Y. (2020). A time-frequency analysis of the thermal radiation background anomalies caused by large earthquakes: A case study of the Wenchuan 8.0 earthquake. Advances in Space Research, 65(1), 435-445.

Wukelic, G. E., Gibbons, D. E., Martucci, L. M., \& Foote, H. P. (1989). Radiometric calibration of Landsat Thematic Mapper thermal band. Remote sensing of environment, 28, 339-347. https://doi.org/10.1016/0034-4257(89)90125-9

Xie, T., Kang, C. L., \& Ma, W. Y. (2013). Thermal infrared brightness temperature anomalies associated with the Yushu (China) M s= 7.1 earthquake on 14 April 2010. Natural Hazards and Earth System Sciences, 13(4), 1105-1111. https://doi.org/10.5194/nhess-13-1105-2013

Xiong, P., \& Shen, X. (2017). Outgoing longwave radiation anomalies analysis associated with different types of seismic activity. Advances in Space Research, 59(5), 1408-1415.

https://doi.org/10.1016/j.asr.2016.12.011

Yao, Q. L., \& Qiang, Z. J. (2010). The elliptic stress thermal field prior to M S 7.3 Yutian, and M S 8.0 Wenchuan earthquakes in China in 2008. Natural hazards, 54(2), 307-322.

https://doi.org/10.1007/s11069-009-9470-4

Zhang, Y., Meng, Q., Ouillon, G., Zhang, L., Hu, D., Ma, W., \& Sornette, D. (2021). Long-term statistical evidence proving the correspondence between tir anomalies and earthquakes is still absent. The European Physical Journal Special Topics, 230(1), 133-150. https://doi.org/10.1140/epjst/e2020-0002484

Zeng, Y., Feng, Z., \& Xiang, N. (2004, September). Assessment of soil moisture using Landsat ETM+ temperature/vegetation index in semiarid environment. In IGARSS 2004. 2004 IEEE International Geoscience and Remote Sensing Symposium (Vol. 6, pp. 4306-4309). leee.

Zhao, X., Pan, S., Sun, Z., Guo, H., Zhang, L., \& Feng, K. (2021). Advances of Satellite Remote Sensing Technology in Earthquake Prediction. Natural Hazards Review, 22(1), 03120001. https://doi.org/10.1061/(ASCE)NH.1527-6996.0000419

\section{Figures}



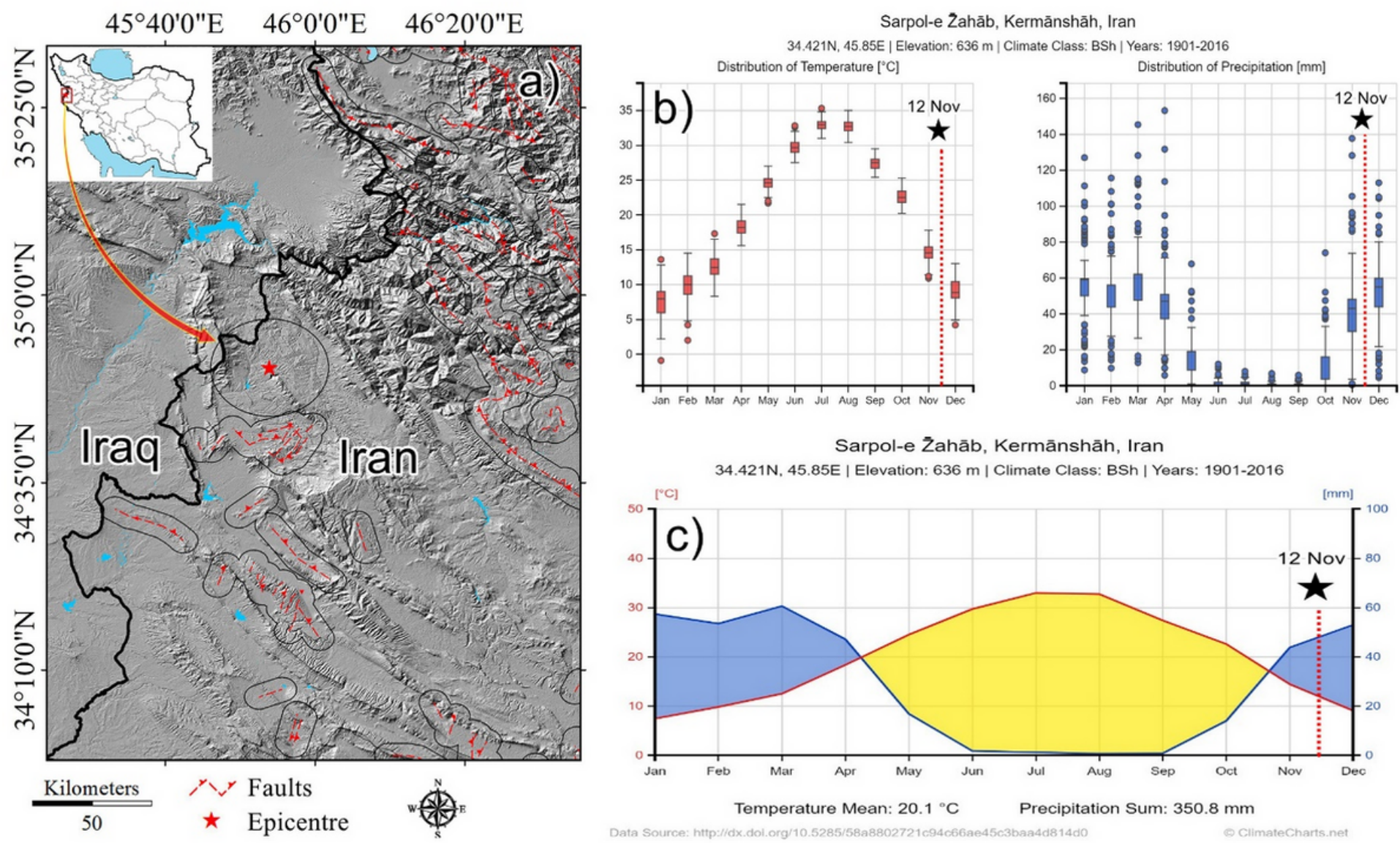

Data Source: http://dx.dol.org/10.5285/58a8802721c94c66ae45c3baa4d814do

Figure 1

Study area situation a location in Iran near Iraq, b temperature distribution $\left({ }^{\circ} \mathrm{C}\right)$ and precipitation distribution (mm) in different months between 1901 and $2016 \mathrm{c}$ amberotermic graph shows dry and wet months, the stars show the earthquake situation on the map and graphs (https://climatecharts.net/ Access date 14 Nov 2019)
$34.4^{\circ} \mathrm{N}, 45.9^{\circ} \mathrm{E}$
Temperature Anomalies
Binomial
2017-2017 Trend
Filter
$\left(+\right.$ inf $f^{\circ} \mathrm{C} /$ Decade)

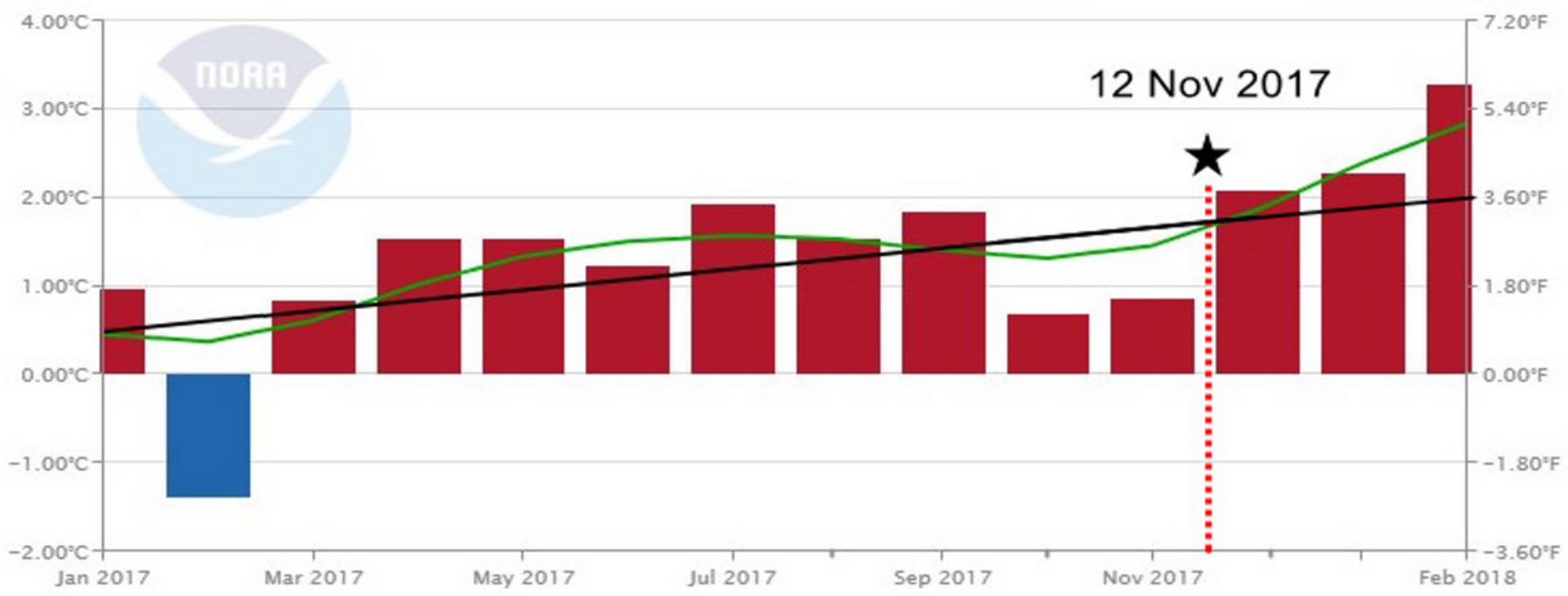




\section{Figure 2}

Earth surface temperature anomaly $\left({ }^{\circ} \mathrm{C}\right)$ in 2017 , the star shows earthquake situation on the map and graphs (https://www.ncdc.noaa.gov/ Access date 14 Nov 2019)

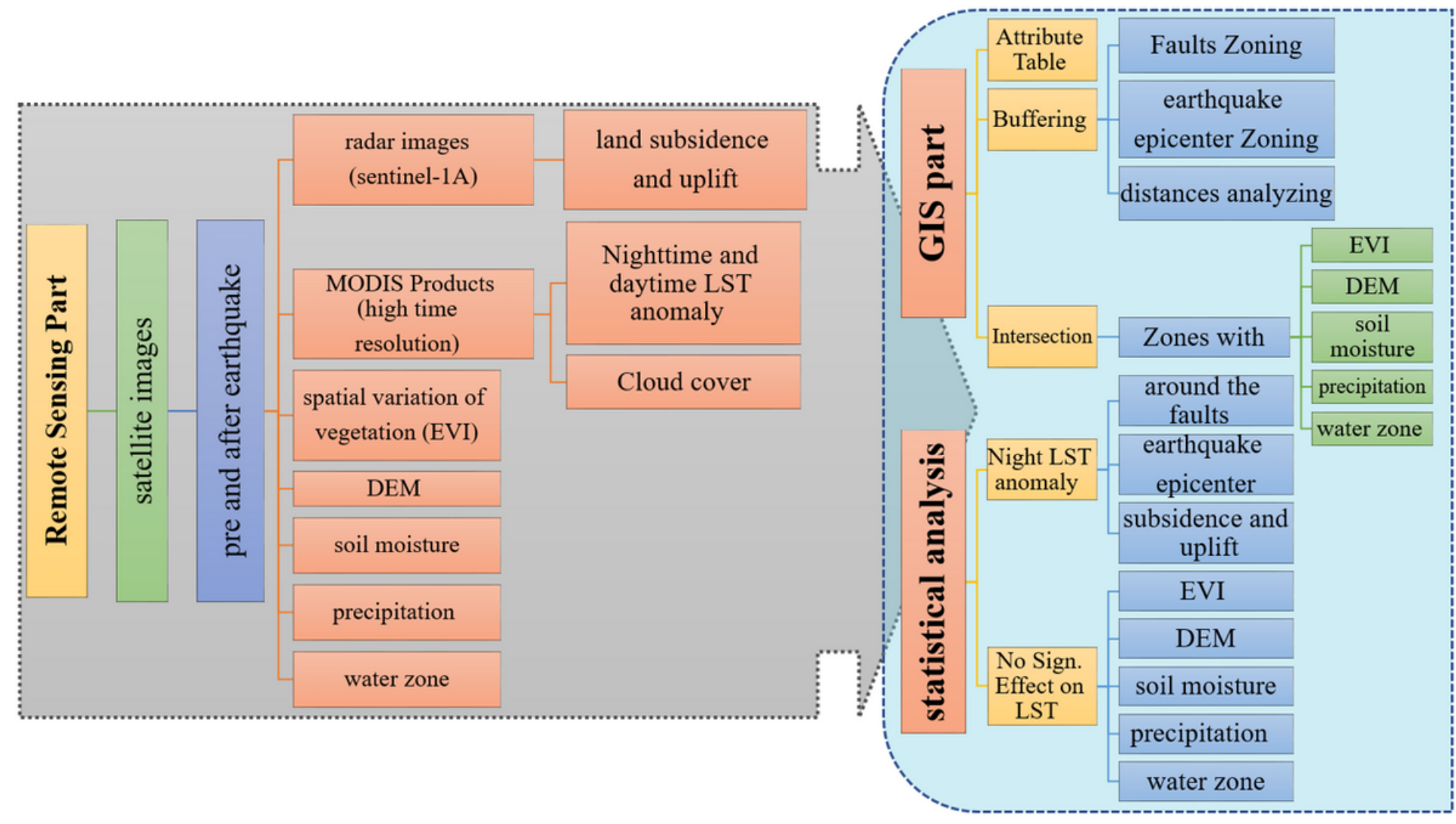

\section{Figure 3}

Flow chart of study stages 


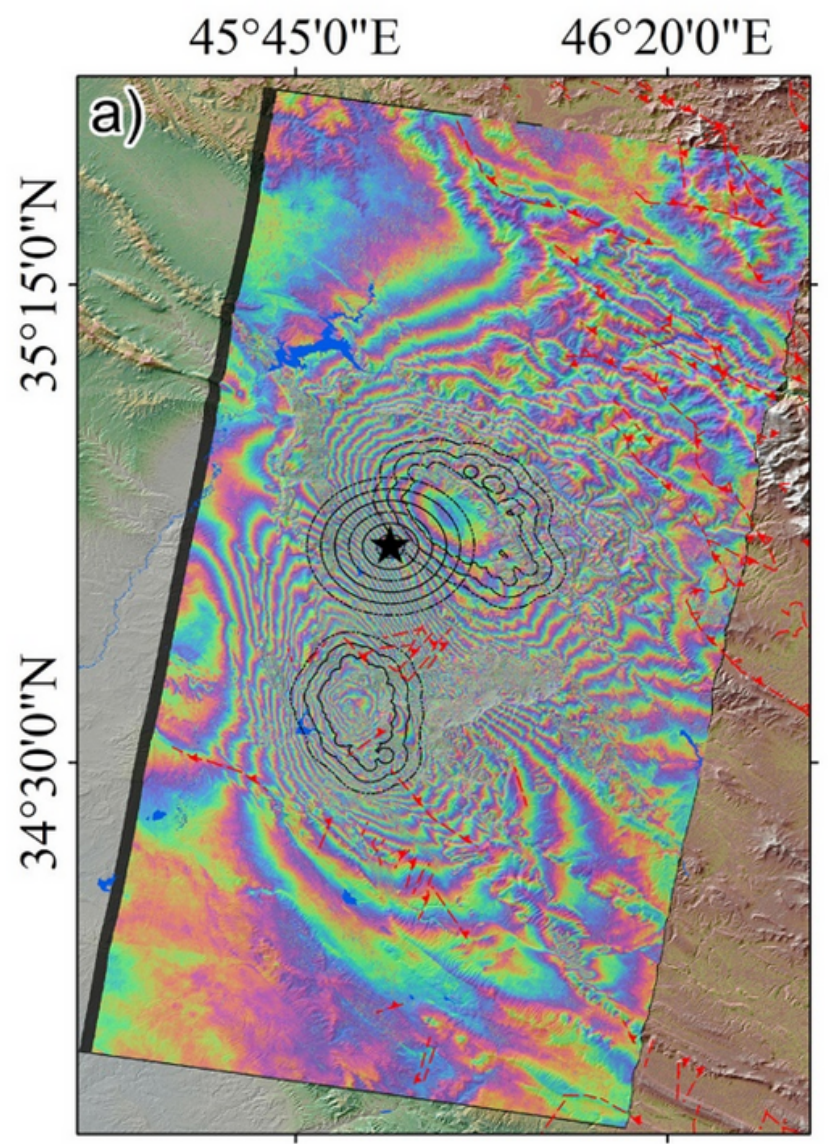

Phase_VV_07Nov2017_19Nov2017 [phase]

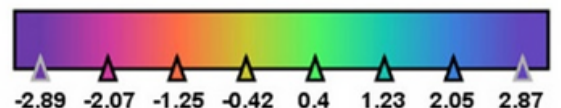

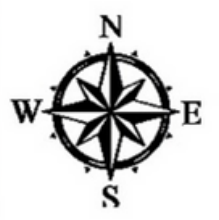

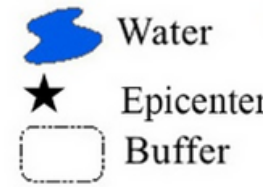

× Fault

DEM

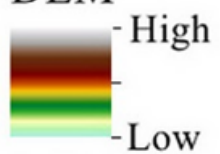

Kilometers

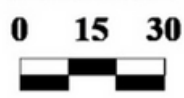

\section{Figure 4}

Using RADAR images in specified of uplift and subsidence on the earthquake, a map of interferogram b map of displacement 

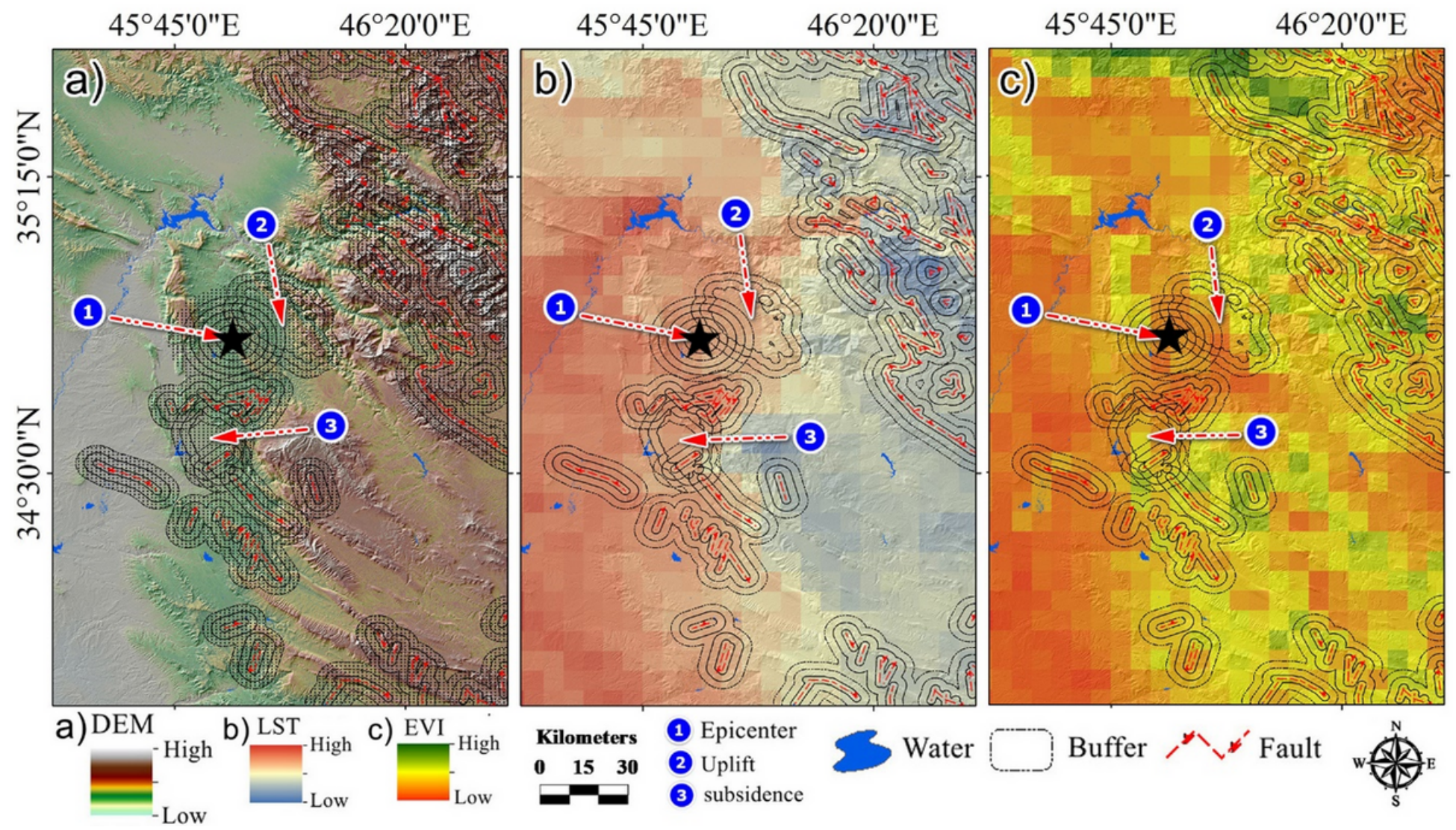

Figure 5

Location of epicenter, fault, uplift and subsidence, altitudes, buffers, water zones, a: situation of earthquake in the Zagros Mountains, b: changing land surface temperature overnight around the features, c: spatial changing of Vegetation coverage around features 


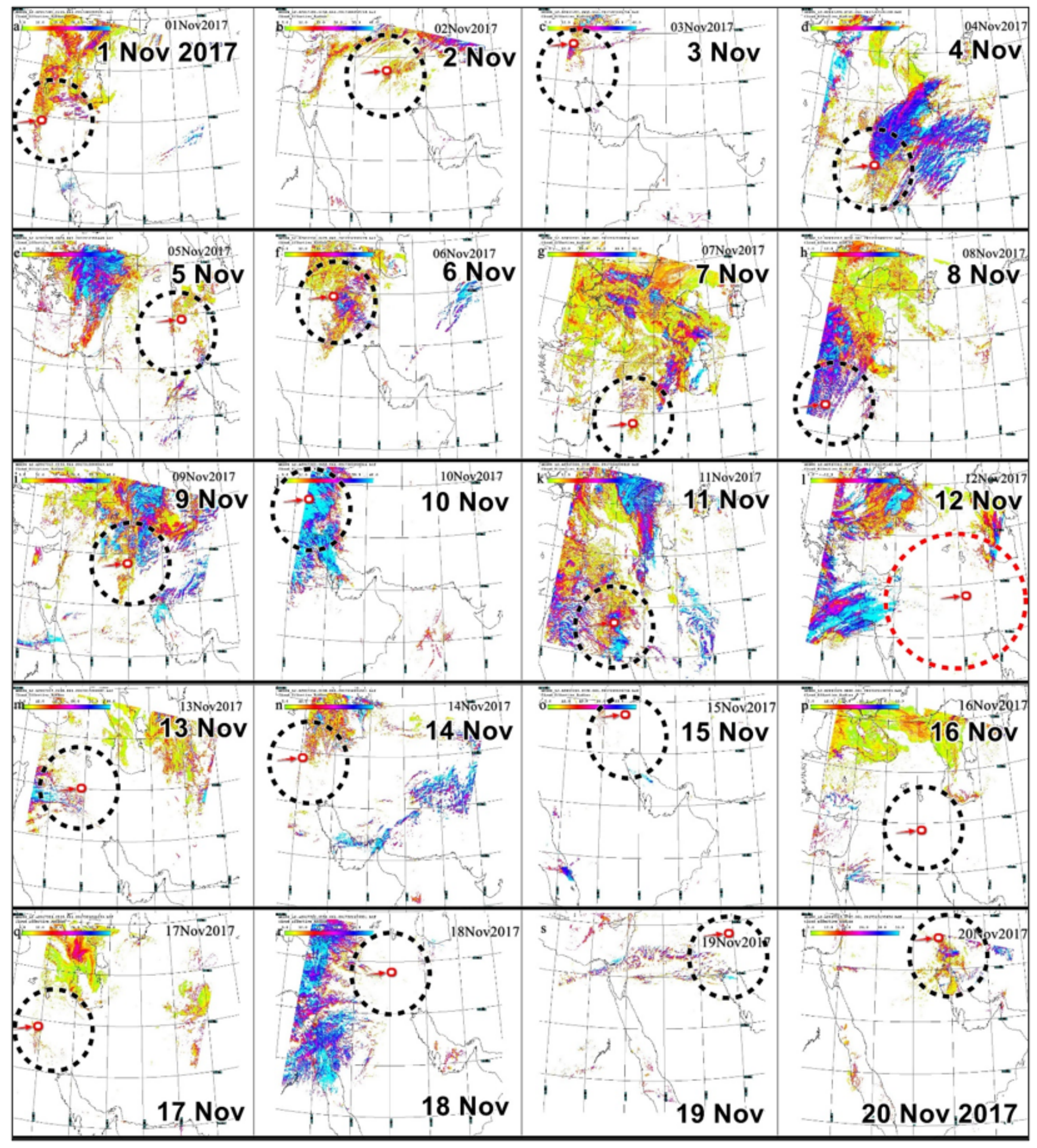

Figure 6

Cloud images of the quake-hit area taken from the MODIS sensor a few days before and after the earthquake 


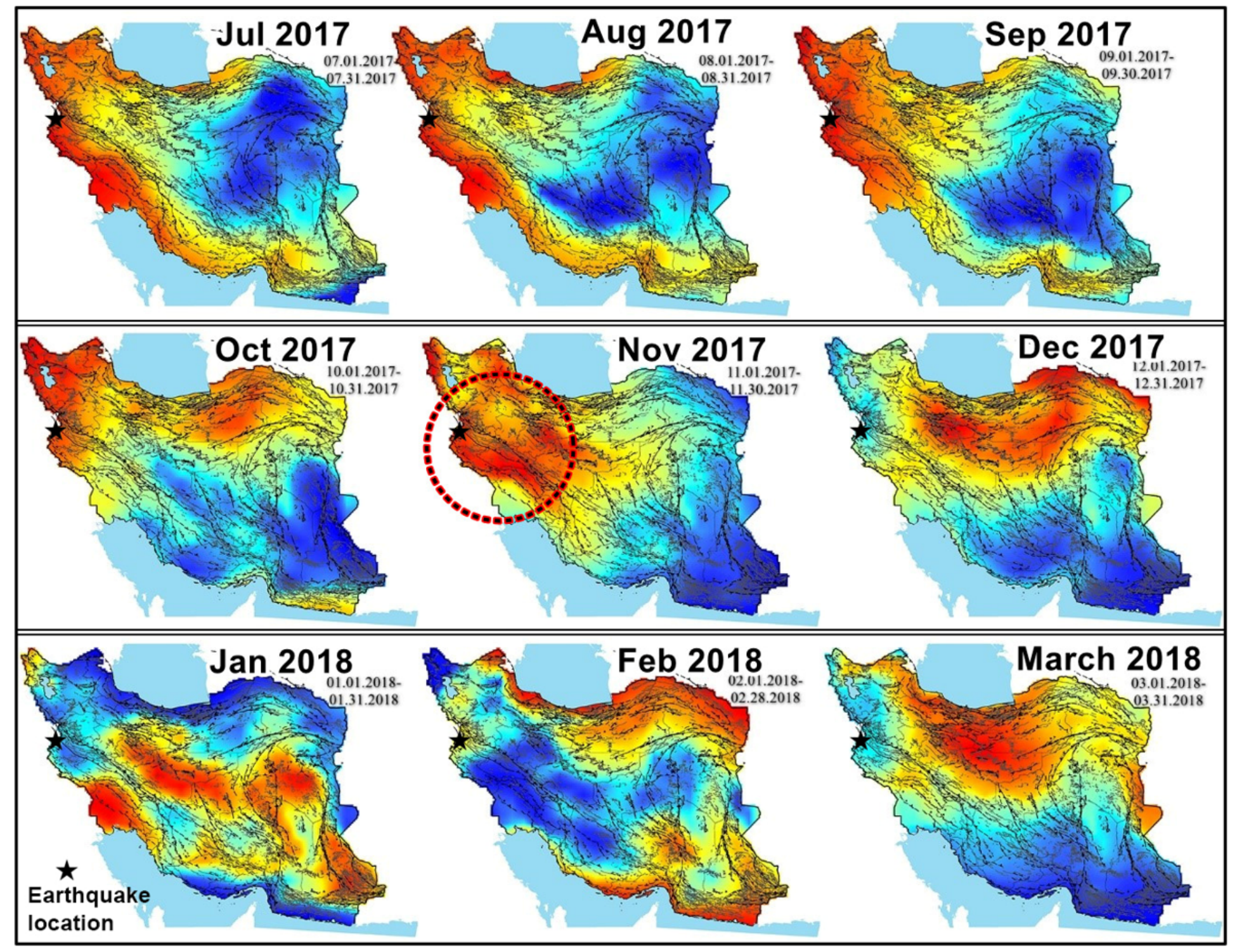

Figure 7

Monthly average of thermal anomalies several months before and after the earthquake in Iran around the epicenter 


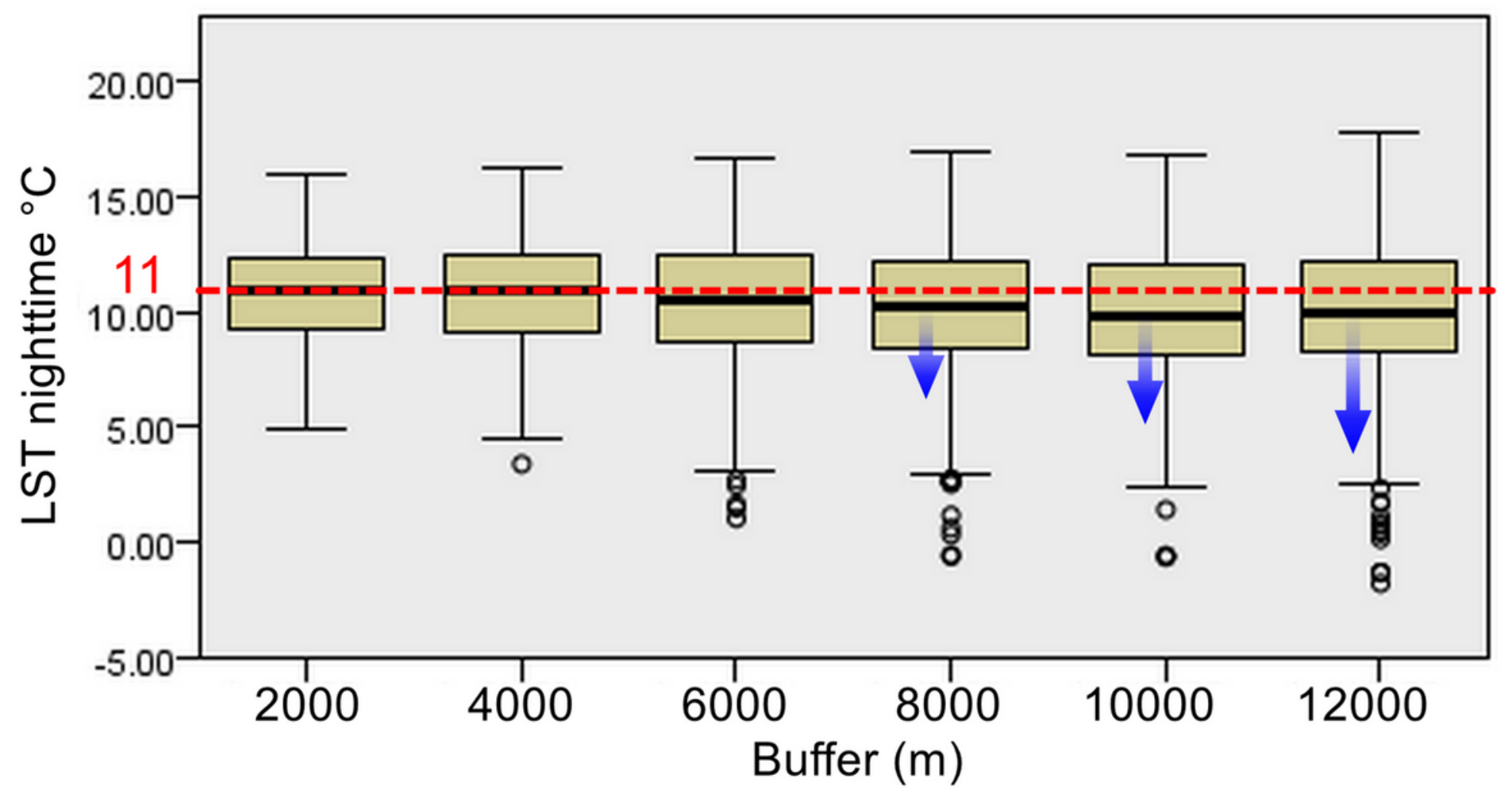

Figure 8

Buffer 2000 to $12000 \mathrm{~m}$ around the picenter of the earthquake, Buffer $2000 \mathrm{~m}$ had max nighttime temperature and buffer $12000 \mathrm{~m}$ has least. Buffers' temperatures are significantly different. This indicates the effect of the earthquake on the temperature of the region. These temperatures were from one week before to one week after the earthquake

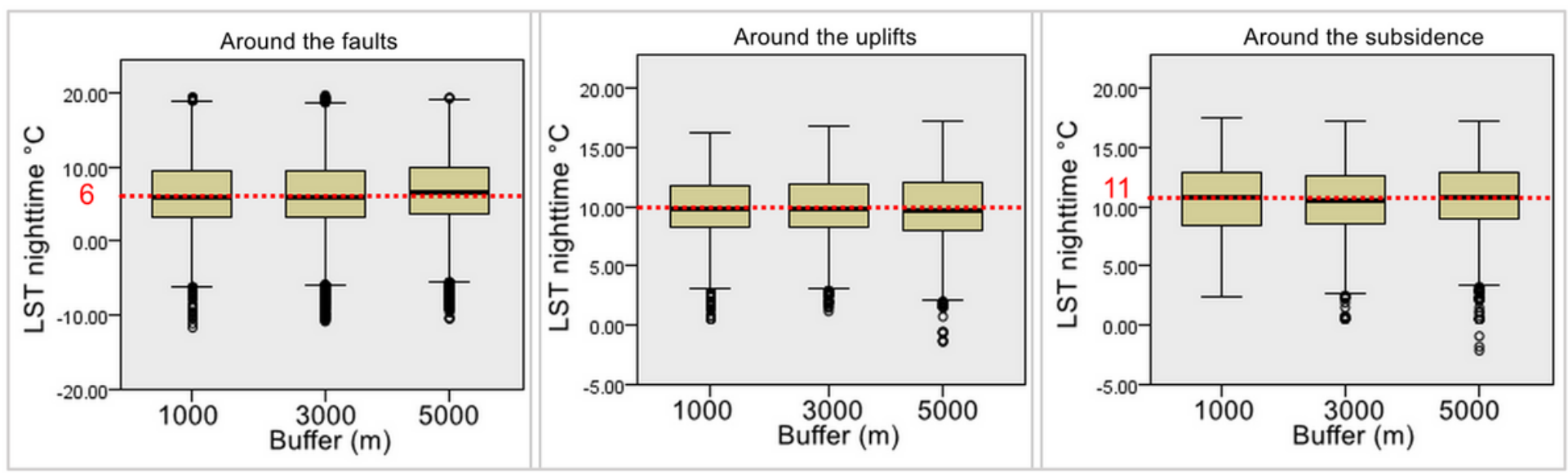

\section{Figure 9}

Statistical comparison of Kruskal-Wallis test of independent samples of nLST from one week before to one week after the earthquake is shown in three buffers of 1000, 3000 and 5000 meters and the difference between the three buffer groups was significant 

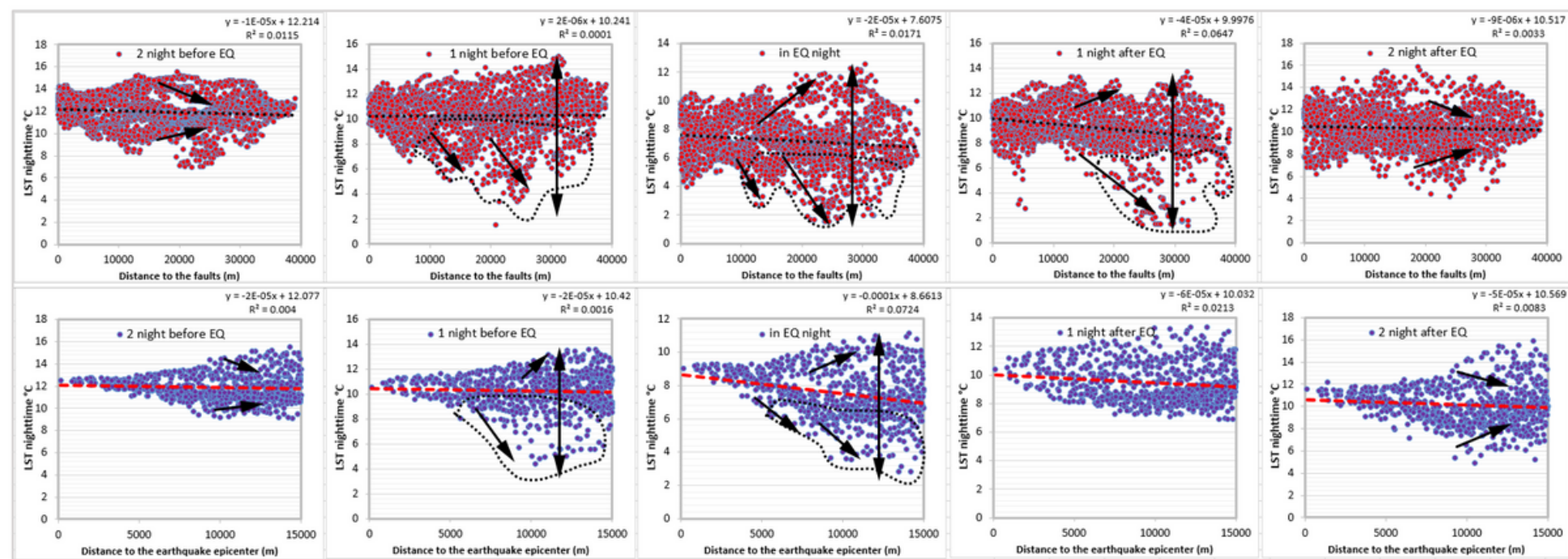

Figure 10

Scatter plot of nLSTand distance to faults (row 1), to earthquake epicenter (row 2), expantion of points and moree steepness of trend line in night of accidenc is obviouse
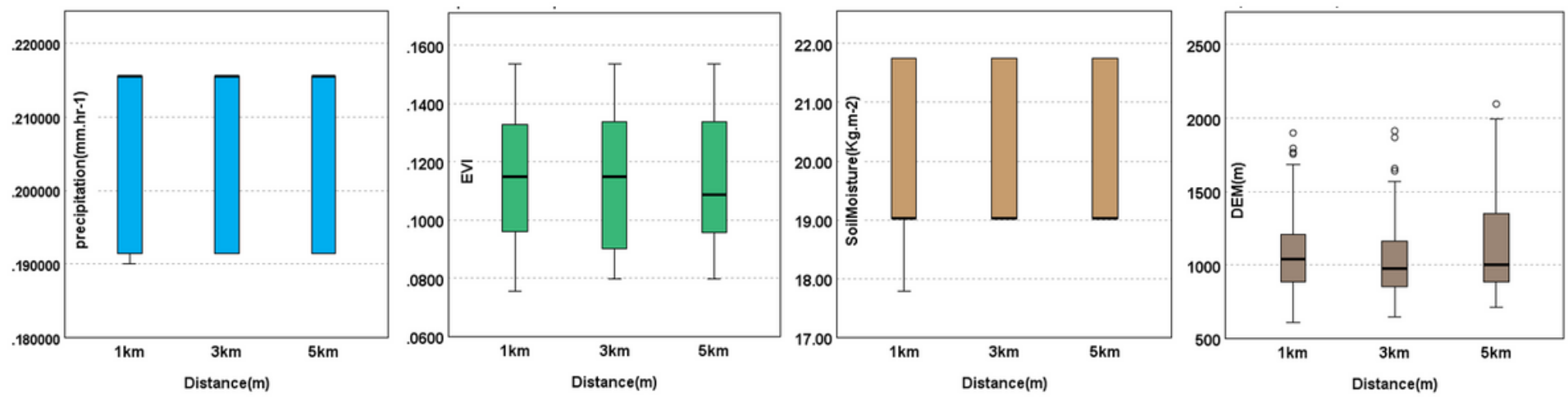

Figure 11

Statistical comparison for cooler factors around uplift center, these factors are same in buffers and have no effect on nLST changes 